were some polyploid cells, but the normal pattern of inheritance of plasma transferrin types from both parents did not indicate either digyny or dispermy. Triploidy has not therefore been shown. It is likely that the XY lymphocytes were of fraternal origin.

The external genitalia resembled those of some other cows with disgenic gonads and absence of Wolffian or penile structures (LOJDA, I968; RIECK, I973). They also had elongated urethrae. Their vestigial gonads had tunical albugineae, evidence of early testicular development. It is suggested that these cases, and possibly the present one, demonstrate the earliest stage of masculinization of the genitalia, in which only the genital sinus is stimulated to form an elongated, male urethra. The gonads then degenerated before the Wolffian system could be stimulated. In the classic freemartin the earliest stage is missing, but the fraternal stimulus provokes testicular development in a second stage while the Wolffian structures are still sensitive. Neither the animals with disgenic testes nor the freemartins achieve the third stage in which the penile structures, derivatives of the genital papilla, are stimulated to full masculinization.

The present case therefore, probably owes the masculinizing of her urethra to her own XXY cells, which may have initiated early growth of disgenic testes, rather than to the influence of her male twin, since elongation of the urethra is usually missing from the classic freemartin syndrome.

We thank Dr. Stephen Main of the Institute of Animal Physiology for the testosterone assay, and Dr. J. G. HALL of A.B.R.O. Edinburgh for the blood group study.

\title{
Etude cytogénétique sur certaines races bovines italiennes en voie de diminution ou menacées de disparition
}

\author{
L. MOLTENI, G. SUCCI, Annamaria de GIOVANNI \\ Istituto di Zootecnia Generale, \\ Facoltà di Agraria-Via Celoria 2-Milano, Italie
}

Dans le cadre des recherches que nous avons entreprises dans le but de caractériser, du point de vue cytogénétique, la population bovine italienne, nous avons considéré, entre les races à viande, quelques-unes dont les effectives sont encore considérables, d'autres qui sont menacées de disparition, à plus ou moins long terme.

Nous rapportons dans cette communication les données relatives aux races suivantes: Romagnola, Chianina, Marchigiana, Modicana, Rendena et Modenese. Notre étude a porté surtout sur les taureaux présents dans les centres d'insémination artificielle ou utilisés, dans certaines zones, pour la monte naturelle.

Parmi les 205 animaux étudiés, tous phénotypiquement normaux, dont I 22 (63 mâles et 59 femelles) appartenaient à la race Romagnola, 48 (44 mâles et 4 femelles) à la Rendena, I6 (I I mâles et 5 femelles) à la Modicana, 8 ( 7 mâles et I femelle) à la Marchigiana, 8 (tous mâles) à la Chianina et 3 (tous mâles) à la Modenese, nous avons pu observer la translocation I/29 dans les suivantes : Romagnola, Modicana, Chianina et Marchigiana.

Seulement en ce qui concerne la race Romagnola, dont nous avons pu faire une enquête systématique plus approfondie, nous rapportons les données relatives à la fréquence de cette anomalie, qui a été de $28,69 \mathrm{p}$. cent à l'état héterozygote et de $3,28 \mathrm{p}$. cent à l'état homozygote.

On peut en outre signaler la présence, dans tous les animaux mâles étudiés de race Rendena, d'un chromosome $Y$ de taille supérieure à la moyenne de l'espèce bovine.

\section{The karyotype of a male Bubalus anoa depressicornis quarlesei Ouwens 1911}

\section{E. SCHEURMANN, H. HOHN and H. FISCHER}

Institut für Tropische, Veterinarmedizin, Wilhelmstrasse I5, Giessen 63, R.F.A.

The karyotype of a male Mountain Anoa calf was found to be $2 n=45$. I 5 autosoms were metacentrics and 28 acrocentrics. The gonosomes are acrocentric. It is assumed that the unpaired metacentric chromosome has been formed by the fusion of two acrocentric autosums. 